\title{
Recent Financial Crises and Regulations on the Credit Rating Agencies
}

\author{
Yilmaz Bayar ${ }^{1}$ \\ ${ }^{1}$ Faculty of Business Administration, Karabuk University, Karabuk, Turkey \\ Correspondence: Yllmaz Bayar, Faculty of Business Administration, Karabuk University, Karabuk, Turkey. Tel: \\ 90-370-433-8262 (2584). E-mail: yilmazbayar@karabuk.edu.tr
}

Received: January 12, 2014

Accepted: January 27, 2014

Online Published: March 2, 2014

doi:10.5430/rwe.v5n1p49

URL: http://dx.doi.org/10.5430/rwe.v5n1p49

\begin{abstract}
Credit rating business firstly emerged in the United States in 1900s and became a part of global financial system together with globalization of financial markets as of mid-1970s. The bankruptcies of corporates such as Enron and Worldcom, and financial crises such as 1997 Asian crisis, Global financial crisis and the Eurozone sovereign debt crisis caused investors and public authorities to investigate the accuracy and reliability of the credit ratings. This study investigates the role of credit rating agencies in the global financial crisis and the Eurozone sovereign debt crisis, and then evaluates adequateness of the regulations on the credit rating agencies which the international bodies, the United States and the European Union have made. We evaluated that the new regulations on the credit rating agencies will probably succeed in increasing transparency and accountability of the credit rating agencies and decreasing over-reliance on credit rating agencies. However it does not seem possible that these new regulations will eliminate the conflicts of interest completely, increase the competition in the credit rating market and decrease the rating shopping in the short run.
\end{abstract}

Keywords: global financial crisis, Eurozone sovereign debt crisis, regulation of the credit rating agencies

\section{Introduction}

Credit rating business firstly emerged in the United States (US) in 1900s and became an important part of international financial markets in parallel with the globalization of financial markets as of mid-1970s. Credit rating agencies (CRA) contribute to the efficiently functioning of financial markets by reducing the information asymmetry between borrowers and lenders (Adelson, 2012). But investors and countries began to investigate the reliability of credit ratings especially after the recent crises and the CRAs also were seen as a part of these crises. So the US, EU (European Union) and the international organizations questioned the functioning of the credit rating market and made some regulations on the CRAs to eliminate the imperfections in the market.

The objective of this study is to evaluate adequateness of the recent regulations on the CRAs in light of the Global financial crisis and the Eurozone sovereign debt crisis. In this context:

- We will firstly overview the credit rating market before the crises,

- Then we will identify the channels which the CRAs contributed to emergence and spread of the recent crises and

- We will evaluate the regulations on the CRAs by the international organizations, the US and the EU,

- Lastly we will evaluate to what extent the recent regulations on the CRAs eliminate the imperfections in the credit rating market by conducting a comparative analysis.

The remainder of this paper is organized as follows. Section 2 reviews the credit rating market, Section 3 investigates roles of CRAs in the Global financial crisis and the Eurozone sovereign debt crisis, Section 4 examines the regulations on the CRAs by international organizations, the US and the EU, Section 5 concludes the paper.

\section{Overview of the Credit Rating Market on the Eve of the Recent Crises}

The CRAs rate debt securities by governments and corporate and also structured finance obligations. A credit rating is opinion of the CRA about the creditworthiness of an obligor with respect to a particular debt security or other financial obligation. Credit ratings have four functions: 
- $\quad$ resolving information asymmetry between issuers and investors by measuring the credit risk of the issuer objectively,

- $\quad$ increasing efficiency and functioning of financial markets,

- $\quad$ providing a means of comparison for all issues of embedded credit risk and providing a consistent global rating scale to help build a portfolio,

- providing market participants with a common standard or language to refer to credit risk (OECD, 2010:5-6).

Credit ratings assigned to securities indicate the risk level of the underlying securities. Therefore credit rating is also an important determinant of interest rates which governments, corporates, banks and insurance companies face in the financial markets (Afonso et al., 2007:7). Since governments and corporates with lower credit rating have more risk premium, they borrow from higher interest rates relative to the ones with higher credit ratings. Credit ratings also enable or disable governments and corporates to access to international financial markets because of national regulations which prohibit investing in debt securities with speculative grade (Elkhoury, 2008:1).

There have been more than 150 CRAs on national, regional or global size all over the world. But the share of major CRAs, namely Moody's, Standard and Poor's (S\&P) and Fitch in credit rating market is about 94\% (OECD, 2010:12). The share of S\&P, Moody's and Fitch in credit rating market respectively is 40\%, 39\% and 15\% (Iva and Vukašin, 2010:3). Therefore the credit rating market also has had an oligopolistic market structure. There were two major causes of this oligopolistic structure. Firstly regulations especially in the US limited the new CRAs' entries to the credit rating market. Because the Securities and Exchange Commission (SEC) designated Moody's, S\&P, and Fitch as Nationally Recognized Statistical Rating Organizations (NRSROs) and NRSRO designation became a significant barrier to entry into the bond-rating business for a long time and only these three firms operated as NRSROs until 2000. Secondly a strong reputation is necessary to operate in the credit rating market. Because S\&P, Moody's and Fitch have existed in the industry for a long time and this made new companies with less experience difficult to enter the credit rating market (White, 2001:11). The oligopolistic structure of the credit rating market enabled the CRAs to take advantage of the market power and also prevented the efficiently functioning of the credit rating market.

CRAs used investor-pays model until 1970s. In this model credit ratings were provided free of charge to issuers, and sold to investors for a fee. CRAs began to use issuer-pays model from the US recession of early 1970s to the present. In this model, issuers whose securities the CRAs rate pay for a rating. Although investor-pays model enabled the CRAs to be independence from the issuer being rated, it did not provide sufficient revenue for the CRAs. Consequently CRAs passed to the issuer-pays pricing model (OECD, 2010:6-7). Thus the CRAs began to be dependent on issuers. On the other hand the credit ratings were used as regulatory purposes especially by the US public authorities and this caused the CRAs to gain regulatory status, thus financial institutions and investors thus became over dependent on CRAs.

Consequently a mutual interdependence surfaced among the CRAs, security issuers and investors. The CRAs have an incentive to overrate the credibility of the debtors for not losing present clients and also attracting more clients (Rafailov, 2011:37), but the CRAs faced little or no risk of loss from inaccurate ratings, while the potential gains from inaccurate ratings increased over time (Partnoy, 2009:4). Security issuers needed high credit ratings in order to create and sell the complex financial instruments. Since the institutional and individual investors could not make valuation about the riskiness of new complex securitized assets together with lack of transparency, they relied on the credit ratings without any questioning (Hull, 2010:7).

The CRAs provided rating and consulting services simultaneously before the recent crises. So conflicts of interest arose when the CRAs offered consulting or other advisory services to the issuers they rated (Rafailov, 2011:38). This meant that the CRAs firstly told issuers what they did and then they rated the issuers in question. This situation also contributed to emergence of conflicts of interest in the credit rating market.

Credit rating is a bilateral process which the CRAs determine ratings based on the information provided voluntarily by the issuers. However the CRAs do not have power to ensure and examine the information and they cannot require any additional information by force (Rafailov, 2011:37). So there is a risk that the issuer can conceal or manipulate information.

The CRAs firstly rated the traditional debt instruments but later they departed from their traditional business by beginning to increasingly rate structured finance and new complex debt products, particularly credit derivatives and began to use complex statistical ratings tools in order to gauge credit risk (Partnoy, 2006:2). The ratings of the 
structured finance securities failed to reflect the creditworthiness of the security being rated due to faulty data, flawed assumptions of the model and the tranched structure of the CDO (Collateralized Debt Obligation) securities (Partnoy, 2006:24).

\section{Roles of Credit Rating in the Recent Crises}

\subsection{Role of Credit Rating Agencies in the Global Financial Crisis}

The outburst of subprime mortgage crisis in the US arising from bursting of speculative bubble which grew up in the US housing market between 1997 and 2006 led to the global financial crisis in September 2008 (Shiller, 2008:1). The US subprime mortgage crisis caused the global financial crisis with effect of the global proliferation of securitized, toxic U.S. subprime mortgages (Greenspan, 2010:202). Securitization became popular in the US especially during the period 1999-2007, many different types of assets such as corporate loans, credit card receivables, auto loans, mortgages were securitized during this period.

The traditional originate-to-hold model was used in the US housing finance system until the early 1970s. The US housing finance system began to shift from depository-based funding to capital markets-based funding with the collapse of Bretton Woods system in 1970s. Government sponsored enterprises Fannie Mae and Freddie Mac bought pools of mortgages from originators, and then bundled together particular pools of mortgages and sold the cash flow rights of the pools to investors as mortgage backed securities (MBS). The other financial institutions would also buy mortgages, bundle them into pools, and issued MBSs (Financial Crisis Inquiry Commission, 2010:3-5) (Figure 1).

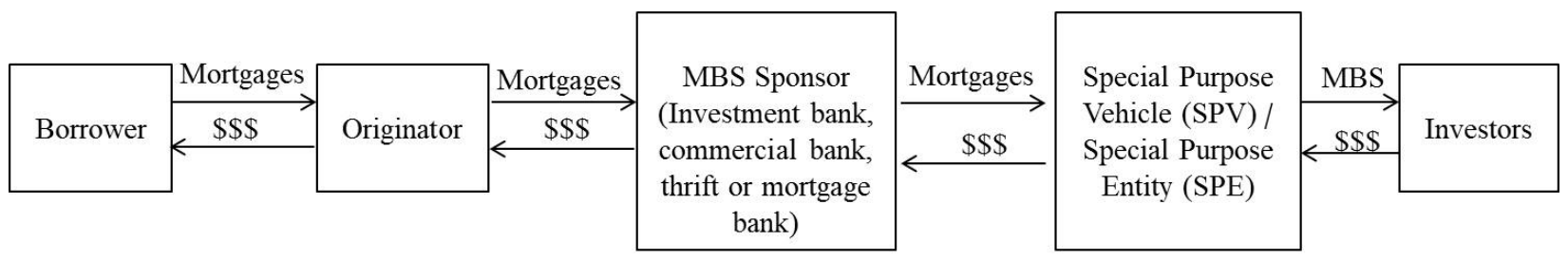

Figure 1. Originate-to-distrubute model

Source: Financial Crisis Inquiry Commission, 2010:5.

CRAs rated MBSs including different CDO tranches by using quantitative tools such as S\&P's' CDO Evaluator, Moody's' CDOROM, and Fitch's VECTOR. This rating process determined prices of securities and risk-weighted capital requirements of the issuers. On the one hand it was very hard for the investors to make valuation of tranches together with lack of transparency (Hull, 2010: 4-7). On the other hand Federal regulations provide incentives for broker-dealers to hold debt with an investment-grade rating from at least two NRSROs and also some regulated investors are limited to investing in securities with investment-grade (Mulligan, 2009:1278). Consequently the market participants relied heavily on the credit ratings assigned to financial instruments including MBSs to determine creditworthy investment options. The favorable ratings are also crucial for the securitization process:

- The use of credit ratings for the regulation by regulatory authorities gave the force of law to the ratings. On the other hand prohibition of banks and savings institutions to hold sub-BBB bonds increased the dependency of issuers on the CRAs.

- MBSs rated AA or better reduced 4\% of capital requirement to $1,6 \%$. On the one hand this contributed to increase in over dependence of issuers on the CRAs; on the other hand this eased financial institutions to buy larger fractions of MBSs.

- $\quad$ Since higher rated tranches gave lower interest rates, securitizers gained higher profits from higher ratings. This motivated securitizers to pressure the CRAs (White, 2009).

When the delinquencies and foreclosures began to increase significantly in the US subprime mortgage markets, many highly rated securities based on mortgages lost value. Inflated credit ratings contributed to the global financial crisis by hiding the real risk of many mortgage-related securities. Although AAA-rated securities historically had less than $1 \%$ probability of incurring defaults, over $90 \%$ of the AAA ratings given to subprime residential mortgage backed securities that originated in the period 2006-2007 were later downgraded by the NRSROs to junk status (United States Senate, Permanent Subcommittee on Investigations, Committee on Homeland Security and Government Affairs, 2011). This revealed the failure of the CRAs about the assessment of the risk for the structured finance instruments. Additionally the CRAs failed to rate banks and companies accurately such as Lehman Brothers, American International Group (AIG) which were negatively affected from subprime crisis because having considerable amount of MBSs. For instance when Lehman Brothers went bankrupt in September 2008, its rating was 
A-, also the insurance company AIG had A- rating when it was bailed out.

\subsection{Role of Credit Rating Agencies in the Eurozone Sovereign Debt Crisis}

The global financial crisis caused increases in public debt stock and budget deficits of some Eurozone countries such as Greece, Portugal, Italy, which had already deteriorations in their public finances because of the fiscal stimulus packages for the stimulating their economies. Firstly nationalization of the banks on the brink of bankruptcy by Ireland raised concerns against the Eurozone and then when Greece revised its budget deficit of 2009 as $12,7 \%$ of GDP, which was the double of the previous estimate, in November 2009, market participants began to investigate creditworthiness of some Eurozone countries and their public finances reached unsustainable level as a result of sharp increases in rates of government bonds after investors' losing their confidence in these countries' sustaining public finances (De Santis, 2012:2). Debt crisis firstly emerged in Greece and then spread to Portugal, Spain, and Italy in a short time.

The CRAs evaluate the ability and willingness of the governments to pay their future debts in full and on time and show their evaluations by sovereign credit ratings (S\&P, 2013a). Since government bonds represent more than $40 \%$ of the bonds issued in global financial markets, sovereign credit ratings are an important indicator for the investors who make investment in government sovereign bonds (S\&P, 2012:2).

Countries in sovereign debt crisis such as Greece, Italy, Portugal, and Spain failed to meet the public finance criteria as of establishment of EMU (European Economic and Monetary Union) and also Austria, Belgium, France and Germany violated these criteria for a long time (Table 1). The Eurozone countries in debt crisis also had deficits in their current accounts and their current deficits reached unsustainable levels over time. Current deficits of Greece, Portugal and Spain in 2008 respectively reached 14,9\%, 12,6\%, and 9,6\% of their GDPs (Eurostat, 2013b). Consequently the Eurozone member countries in debt crisis did not experience any significant positive developments in their economies after joining the EMU, while increasing budget and current account deficits and public debt stocks made their economies vulnerable in case of a negative development in global economy.

Table 1. Eurozone countries violating public finance criteria of EMU

\begin{tabular}{|c|c|c|}
\hline Year & Countries Violating Criterion of Budget Deficits & $\begin{array}{c}\text { Countries Violating Criterion of Government } \\
\text { Debt }\end{array}$ \\
\hline 1999 & - & $\begin{array}{c}\text { Austria, Belgium, Germany, Italy, Netherlands, } \\
\text { Spain }\end{array}$ \\
\hline 2000 & Portugal & Austria, Belgium, Germany, Italy \\
\hline 2001 & Germany, Greece, Italy, Portugal & Austria, Belgium, Greece, Italy \\
\hline 2002 & France, Germany, Greece, Italy, Portugal & Austria, Belgium, Germany, Greece, Italy \\
\hline 2003 & $\begin{array}{c}\text { France, Germany, Greece, Italy, Netherlands, } \\
\text { Portugal }\end{array}$ & $\begin{array}{c}\text { Austria, Belgium, France, Germany, Greece, } \\
\text { Italy }\end{array}$ \\
\hline 2004 & $\begin{array}{c}\text { Austria, France, Germany, Greece, Italy, } \\
\text { Portugal }\end{array}$ & $\begin{array}{c}\text { Austria, Belgium, France, Germany, Greece, } \\
\text { Italy, Portugal }\end{array}$ \\
\hline 2005 & Germany, Greece, Italy, Portugal & $\begin{array}{l}\text { Austria, Belgium, France, Germany, Greece, } \\
\text { Italy, Portugal }\end{array}$ \\
\hline 2006 & Greece, Italy, Portugal & $\begin{array}{c}\text { Austria, Belgium, France, Germany, Greece, } \\
\text { Italy, Portugal }\end{array}$ \\
\hline 2007 & Greece, Portugal & $\begin{array}{c}\text { Austria, Belgium, France, Germany, Greece, } \\
\text { Italy, Portugal }\end{array}$ \\
\hline 2008 & France, Greece, Ireland, Malta, Portugal, Spain & $\begin{array}{c}\text { Austria, Belgium, France, Germany, Greece, } \\
\text { Italy, Malta, Portugal }\end{array}$ \\
\hline 2009 & $\begin{array}{c}\text { Austria, Belgium, France, Ireland, Italy, } \\
\text { Germany, Greece, Malta, Netherlands, Portugal, } \\
\text { Spain, Slovakia, Slovenia, Greek }\end{array}$ & $\begin{array}{l}\text { Austria, Belgium, France, Germany, Greece, } \\
\text { Ireland, Italy, Malta, Netherlands, Portugal }\end{array}$ \\
\hline
\end{tabular}

Source: Eurostat, 2013a.

The CRAs did not make any assessments despite the deteriorations in macroeconomic indicators of these Eurozone countries until outburst of sovereign debt crisis; even they increased sovereign credit ratings of these countries in the expectation that there would be an economic convergence among the Eurozone member countries after establishment of the EMU. Increases in sovereign credit ratings of Eurozone countries in debt crisis contributed these countries to 
borrow at low rates and also misled the investors who made investments in the sovereign bonds of these countries.

Moreover the successive great downgrades in sovereign credit ratings of economically troubled Eurozone member countries after outburst of crisis deepened the crisis and also the CRAs created a downgrade spiral in this way. Downgrades increased government bond rates by increasing risk level of government bonds and increasing borrowing rates raised concerns about sustainability of sovereign debt, this in turn led further downgrades (Bayar, 2012:30). You can see the number of upgrades and downgrades which were made in the sovereign credit ratings of Eurozone countries and distribution of rating changes by countries between January 2008 and December 2012 in Table 3-4. Fitch, Moody's and S\&P made a total of 201 changes in long term foreign currency debt ratings/ outlooks of Eurozone member countries. Changes in long term foreign currency debt ratings consisted of 10 rating upgrades, 116 rating downgrades, 17 positive variations and 58 negative variations outlook. Rating downgrades and negative variations in outlooks constituted about $86,5 \%$ of changes in sovereign credit ratings of Eurozone countries.

Table 2. Number of upgrades and downgrades by Fitch, Moody's and S\&P

\begin{tabular}{lccccc}
\hline CRA & $\begin{array}{c}\text { Total } \\
\text { Changes }\end{array}$ & Upgrades & Downgrades & Upgrades & Downgrades \\
\hline $\begin{array}{l}\text { Fitch } \\
\text { Long term foreign currency }\end{array}$ & 54 & 4 & 33 & 4 & 13 \\
$\begin{array}{l}\text { rating } \\
\begin{array}{l}\text { Moody's } \\
\text { Long term foreign currency } \\
\text { rating }\end{array}\end{array}$ & 68 & 0 & 40 & 5 & 23 \\
$\begin{array}{l}\text { Standard\&Poor's } \\
\begin{array}{l}\text { Long term foreign currency } \\
\text { rating }\end{array}\end{array}$ & 79 & 6 & 43 & 8 & 22 \\
$\begin{array}{l}\text { Total (Foreign currency } \\
\text { rating) }\end{array}$ & 201 & 10 & 116 & 17 & 58 \\
\hline
\end{tabular}

Source: S\&P, 2013b; Moody’s, 2013b and Fitch, 2012.

Table 3 . Number of upgrades and downgrades by country

\begin{tabular}{lccccc}
\hline \multirow{2}{*}{ Country } & \multirow{2}{*}{ Total Changes } & \multicolumn{2}{c}{ Ratings } & \multicolumn{2}{c}{ Outlooks } \\
& & Upgrades & Downgrades & Upgrades & Downgrades \\
\hline Austria & 3 & 0 & 1 & 0 & 2 \\
Belgium & 7 & 0 & 3 & 0 & 4 \\
Cyprus & 23 & 1 & 18 & 0 & 3 \\
Estonia & 15 & 4 & 3 & 5 & 1 \\
Finland & 1 & 0 & 0 & 0 & 3 \\
France & 5 & 0 & 2 & 0 & 7 \\
Germany & 1 & 0 & 0 & 0 & 7 \\
Greece & 36 & 3 & 23 & 3 & 3 \\
Ireland & 26 & 0 & 15 & 4 & 2 \\
Italy & 10 & 0 & 7 & 0 & 2 \\
Luxembourg & 2 & 0 & 0 & 0 & 4 \\
Malta & 5 & 0 & 3 & 0 & 5 \\
Netherlands & 2 & 0 & 0 & 0 & 3 \\
Portugal & 19 & 0 & 14 & 1 & 2 \\
Slovakia & 12 & 2 & 2 & 3 & 1 \\
Slovenia & 16 & 0 & 10 & 0 & 2 \\
Spain & 18 & 0 & 15 & 0 & 2 \\
\hline
\end{tabular}

Source: S\&P, 2013b; Moody's, 2013 and Fitch, 2012.

\section{Regulations on the Credit Rating Agencies}

Although the credit rating business emerged in 1900s there were no significant regulations on the CRAs at the national or international levels until 2000s. 


\subsection{International Regulations on the Credit Rating Agencies}

The International Organization of Securities Commissions (IOSCO) issued "Statement of Principles Regarding the Activities of Credit Rating Agencies" in September 2003, and then "Code of Conduct Fundamentals for Credit Rating Agencies" in December 2004 on the eve of global financial crisis. These two arrangements contained voluntary principles for the CRAs about the quality and integrity of the rating process, independence and avoidance of conflicts of interest, responsibilities to the investing public and issuers, and public disclosure of their own code of conduct (IOSCO, 2003 and 2004).

IOSCO modified the Code of Conduct Fundamentals for CRAs given the role of the CRAs in rating of structured finance transactions and the changes are generally on the issues that arose in relation to the activities of CRAs in the market for structured finance products. The main changes in the revised Code are as follows:

- Considerations about the rating of structured finance securities,

- Considerations about the independence ofthe CRAs and avoidance of conflicts of interest,

- Considerations about responsibilities of the CRAs to the investors and issuers (IOSCO, 2008).

However the IOSCO Code still has contained no specific rules concerning methodologies, it only determined the main considerations which the CRAs pay attention to during the credit rating process. On the other hand the Financial Stability Board (FSB) endorsed principles to reduce the overreliance of authorities and financial institutions on credit ratings in October 2010. Also the Basel Committee on Banking Supervision also proposed to reduce overreliance on CRAs' ratings in the regulatory capital framework (European Commission, 2013:3).

\subsection{Regulations on the Credit Rating Agencies in the United States}

The first regulation on the CRAS by the US public authorities was that the banks were legally prohibited from investing in speculative investment securities as determined by recognized rating manuals in 1936 and then a similar regulation was adopted for the insurance companies in 1948 (White, 2010: 173). Apart from these, no significant regulations were made for the CRAS until 1975. The SEC decided to make capital requirements sensitive to the riskiness of broker-dealers' bond portfolios and began to use the ratings as the indicators of risk in 1975. However the SEC designated Moody's, S\&P and Fitch as NRSROs and endorsed the ratings of NRSROs for the determination of the broker-dealers' capital requirements. NRSRO designation became a significant barrier to entry into the credit rating market and only these three firms operated as NRSROs until 2000. Credit ratings by CRAs must be approved SEC according to this first formal regulation in 1975, but there were no clear rules about approval procedure and also no requirements concerning transparency, conflict of interests and quality of credit rating business (Cinquegrana, 2009:4).

CRA Reform Act of 2006 was enacted with the purpose of improving ratings quality, protection of investors and promoting accountability, transparency, and competition in the credit rating market after failure of major CRAs in rating of companies such as Enron, WorldCom which headed for bankruptcy. The Act was concerned with the issuance and use of credit ratings and the main changes were as follows:

- The Act changed the NRSRO designation process in order to increase the number of NRSROs and thus competition among the CRAs. While the SEC historically designated NRSROs through the no-action letter process, a CRA may seek designation by submitting an application to the SEC with this law.

- The law also granted the SEC to inspect CRAs about adoption by NRSROs of specific policies and procedures to prevent the misuse of material, non-public information and regarding the management of potential conflicts of interest (Cahill Gordon \& Reindel LLP, 2006).

The preparation of regulations on the CRAs was accelerated after the US subprime mortgage crisis and the Global financial crisis. In this context newly enacted Dodd-Frank Wall Street Reform and Consumer Protection Act SEC had some directions regarding the CRAs and also SEC issued a regulatory scheme about the CRAs. The Dodd-Frank Wall Street Reform and Consumer Protection Act addressed the increased accountability, conflicts of interest and ratings accuracy, reliance on ratings by federal agencies, and public disclosure of rating methodologies regarding the CRAs. The important considerations in the act were as follows:

- Office of Credit Ratings was established within the body of SEC that will oversee NRSROs and administer SEC rules with respect to NRSRO credit rating practices.

- $\quad$ The SEC is authorized to deregister a CRA for providing bad ratings over time.

- The SEC is required to examine NRSROs at least once a year and make key findings public. 
- $\quad$ NRSROs are required to disclose their procedures and methodologies which they use in the credit rating.

- $\quad$ NRSROs are required to provide the SEC with information regarding the reliability, accuracy, and quality of information, including information from third parties used in the issuance of ratings.

- $\quad$ NRSROs are required to establish internal controls that will implement, enforce, and maintain credit rating policies, procedures, and methodologies, and also each NRSRO is required to have a Board of Directors, at least half of whom are independent of the NRSRO.

- Investors can bring private rights of action against ratings agencies for a knowing or reckless failure to conduct a reasonable investigation of the facts or to obtain analysis from an independent source.

- $\quad$ Ratings analysts are required to pass qualifying exams and have continuing education.

- Use of NRSRO ratings by many statutory and regulatory requirements is eliminated and thus over-reliance on ratings is reduced and investors are encouraged to conduct their own analysis (Harper, 2011:1948-1951).

The SEC also adopted a number of new rules concerning annual reports on internal controls, conflicts of interest with respect to sales and marketing practices, look-backs when credit analysts leave the NRSRO, fines and penalties, disclosure of performance statistics, application and disclosure of credit rating methodologies, form disclosure of data and assumptions underlying credit ratings, among other things, disclosure about third party due diligence, analyst training and testing, consistent application of rating symbols and definitions, specific and additional disclosure for ratings related to ABS products in accordance with the Dodd-Frank act (SEC, 2011).

The SEC established a new rating framework about the credit rating process. Accordingly sponsors of securitization transactions seeking ratings will create a password-protected website to which they must send all documents and data to be evaluated by the CRA. All qualified agencies have access to the website and any additional information communicated orally or in writing from issuer to invited CRA. Therefore uninvited agencies also are allowed to issue unsolicited ratings on a transaction and all qualified agencies have the same access to data and the same right to issue a rating (Borod and Bartlam, 2012).

\subsection{Regulations on the Credit Rating Agencies in the European Union}

The EU made its first regulatory approaches to the CRAs in the outburst of the Enron scandal. But the European Commission concluded that no legislative initiatives were needed and IOSCO Code of Conduct was enough for the time being in 2006. However the EU noticed that there were serious weaknesses in the existing EU rules on credit ratings after global financial crisis and the Eurozone sovereign debt crisis and began to make regulations on the CRAs.

The first regulation (Regulation No 1060/2009)(CRA I) on the CRAs make registration of the CRAs operating in the EU compulsory, but it was not clear who would supervise the CRAs (Managio-Vekil, 2012:34-35). Then European Securities and Markets Authority (ESMA) was established as an independent EU Authority in order to contribute to safeguarding the stability of the EU's financial system on 1 January 2011. ESMA is responsible for the registration and supervision of the CRAs (ESMA, 2011:5).

The second regulation (Regulation No 513/2011) (CRA II) determines ESMA's authority and responsibilities. ESMA is also authorized to inspect CRA premises and to request information from the CRAs, enforcement powers against the CRAs that violated CRA I rules. CRA II required issuers of structured finance products to provide access to information for all interested rating agencies in addition to appointed the CRAs with a view to encouraging unsolicited ratings which would lead to competition in the credit rating markets (Borod and Bartlam, 2012).

The third regulation (Regulation No 462/2013) (CRA III) aims to address regulatory concerns related to the credit rating market, including over-reliance by investors and financial services firms on credit rating, conflicts of interests and significant barriers to market entry by new CRAs. However, the CRA III imposes new obligations not only on the CRAs but also on issuers, originators and sponsors in connection with structured finance instruments (EU Law, 2013).

\section{Conclusion}

Credit rating business firstly emerged in the US in 1900s and credit ratings were used as indicator of riskiness of debt securities for the investments in government and corporate bonds and regulatory purposes in the US. Later the CRAs became important actors in the global financial system due to growth in capital markets and credit derivative markets and financial globalization. However there were no significant regulations on the CRAs nationally and internationally until 2000s. The credit rating market was almost unregulated before the global financial crisis and the 
Eurozone sovereign debt crisis. Since the recent crises revealed that credit ratings failed to reflect the real risk of securities and obligors one more time, the international bodies, the US and the EU have made some regulations on the CRAs. The new regulations on the CRAs especially by the US and the EU has included periodic inspections for the operations of CRAs and monitoring the ratings. Also the CRAs are required to disclose both their procedures and methodologies and changes in the procedures and methodologies over time. These new regulations are expected to increase transparency and accountability of the CRAs.

However reducing the use of credit ratings for regulatory purposes and encouraging investors to conduct their own analysis in the context of new regulations are evaluated to decrease conflict of interests partially. Because the credit ratings of securities are still an important determinant of issuers' borrowing cost or return rate. Therefore conflicts of interests among the related parties in the credit rating process continue to pose an obstacle to the efficiently functioning of the credit rating market. The new regulations also allow all invited or uninvited CRAs to have access to all documents and data which issuers provide. But it does not seem possible for the CRAs to provide a rating without any economic motives. So this measure will not be effective in preventing rating shopping between issuers and CRAs. Although the new regulations has increased the number of CRAs (the number of CRAs accepted NRSRO by the US increased 10 and the CRAs certified by the EU reached 37), the share of major CRAs S\&P, Moody's and Fitch in the credit rating market has still been about $94 \%$.

Moreover the regulations the CRAS has included no considerations about the change of the current issuer-pay system which was one of the major reasons behind the failure of the CRAs and also there has been no regulation on nonliability of the CRAs in case of inaccurate ratings. But investors can bring private rights of action against ratings agencies for a knowing or reckless failure to conduct a reasonable investigation of the facts.

Consequently the recent regulations on the CRAs are expected to increase transparency and accountability of the CRAs and decrease over-reliance on the CRAs. But it does not seem possible that the recent regulations will eliminate conflicts of interest completely, increase competition among the CRAs and decrease the rating shopping in the short run. So further regulations are needed for efficiently functioning of the credit rating market or alternatively a public CRA may be established as an alternative to the private CRAs.

\section{References}

Adelson, M. H. (2012). The Role of credit ratings in the financial system. Retrieved June 6, 2013, from http://www.standardandpoors.com/ratings/articles/en/us/?articleType=HTML\&assetID=1245333790527

Afonso, A., Gomes, P., \& Rother, P. (2007). What hides behind sovereign debt ratings? European Central Bank Working Paper Series, No.711, Frankfurt.

Bayar, Y. (2012). Evaluation of sovereign risk ratings in consideration of European sovereign debt crisis. 6th International Scientific Conference Managing and Modeling of Financial Risks, VŠB -Technical University Ostrava, Ostrava, September 10-11.

Borod, R. S., \& Bartlam, M. (2012). Rating agency reform in the EU and the U.S., Retrieved July 16, 2013, from http://www.dlapiper.com/files/upload/DLAPiper_CF07152012.pdf

Cahill Gordon, \& Reindel LLP. (2006). Credit agency reform act of 2006. Retrieved June 22, 2013, from http://www.cahill.com/publications/firm-memoranda/0000071/_res/id=Attachments/index=0/102706_Credit\%2 0Agency\%20Reform\%20Act\%20of\%202006.pdf

Cinquegrana, P. (2009). The reform of the credit rating agencies: A comparative perspective. ECMI Policy Brief Series, No.12, Brussel.

De Santis, R.A. (2012). The Euro area sovereign debt crisis: Safe haven, credit rating agencies and the spread of the fever from Greece, Ireland and Portugal. European Central Bank Working Papers, No.1419, Frankfurt.

Elkhoury, M. (2008). Credit rating agencies and their potential impact on developing countries. United Nations Conference on Trade and Development Discussion Papers, No.186, Geneva.

ESMA (2011). Annual report 2011. Retrieved June 22, 2013, from http://www.esma.europa.eu/system/files/esma-2011.pdf

EU Law. (2013). Regulation (EU) No 462/2013 of the European Parliament and of the Council of 21 May 2013 amending Regulation (EC) No 1060/2009 on Credit Rating Agencies. Retrieved June 22, 2013, from http://eur-lex.europa.eu/LexUriServ/LexUriServ.do?uri=OJ:L:2013:146:0001:0033:EN:PDF 
European Commission. (2013). New rules on credit rating agencies (CRAs) enter into force - Frequently asked questions. Retrieved June 20, 2013, from http://europa.eu/rapid/press-release_MEMO-13-571_en.htm

Eurostat. (2013a). Public finance statistics. Retrieved June 10, 2013, from http://appsso.eurostat.ec.europa.eu/nui/submitViewTableAction.do

Eurostat. (2013b). Balance of current account. Retrieved June 10, 2013, from $\mathrm{http}: / /$ epp.eurostat.ec.europa.eu/tgm/table.do?tab=table\&init=1\&language $=$ en\&pcode $=$ tec00043

Financial Crisis Inquiry Commission. (2010). Preliminary staff report: Securitization and the mortgage crisis. Retrieved June 20, 2013, from http://fcic-static.law.stanford.edu/cdn_media/fcic-reports/2010-0407-Preliminary_Staff_Report_-_Securitization _and_the_Mortgage_Crisis.pdf

Fitch. (2012). Complete sovereign rating history. Retrieved July 5, 2013, from $\mathrm{http}: / / \mathrm{www}$. fitchratings.com/web_content/ratings/sovereign_ratings_history.xls

Greenspan, A. (2010). The crisis. Brookings Papers on Economic Activity, Spring 2010, 201-246.

Harper, S. (2011). Credit rating agencies deserve credit for the 2007-2008 Financial crisis: An analysis of CRA liability following the enactment of the Dodd-Frank Act. Washington and Lee Law Review, 68(4), 1925-1972.

Hull, J. (2010). Credit ratings and the securitization of subprime mortgages. Federal Reserve Bank of Atlanta 2010 Financial Markets Conference. Federal Reserve Bank of Atlanta, Georgia, May 11.

IOSCO. (2003). IOSCO Statement of principles regarding the activities of credit rating agencies. Retrieved June 20, 2013, from http://www.fsa.go.jp/inter/ios/20030930/02.pdf

IOSCO. (2004). Code of conduct fundamentals for credit rating agencies. Retrieved June 20, 2013, from http://www.iosco.org/library/pubdocs/pdf/IOSCOPD180.pdf

IOSCO. (2008). The role of credit rating agencies in structured finance markets. Retrieved June 20, 2013, from http://www.iosco.org/library/pubdocs/pdf/IOSCOPD270.pdf

Iva, V., \& Vukašin, K. (2010). The role and significance of rating agencies during the crisis period. International Conference OF Faculty of Economics Sarajevo, Sarajevo, October 14-15.

Manaigo-Vekil, A. (2012). The regulation of credit rating agencies in Europe and ESMA's supervisory power. Columbia Journal of European Law, 18, 33-45.

Moody's. (2013). Sovereign rating history. Retrieved June 16, 2013, from http://pages.stern.nyu.edu/ adamodar/pc/datasets/ctrypremJune2012.xls

Mulligan, C.M. (2009). From AAA to F: How the credit rating agencies failed America and What can be done to protect investors. Boston College Law Review, 50(4), 275-1305.

OECD. (2010). Competition and credit rating agencies. Retrieved June 6, 2013, from http://www.oecd.org/regreform/sectors/46825342.pdf

Partnoy, F. (2006). How and why credit rating agencies are not like other gatekeepers. Retrieved June 25, 2013, from http://ssrn.com/abstract $=900257$

Partnoy, F. (2009). Overdependence on credit ratings was a primary cause of the crisis. Retrieved June 25, 2013, from http://ssrn.com/abstract $=1430653$

Rafailov, D. (2011). The failures of credit rating agencies during the global financial crisis - causes and possible solutions. Economic Alternatives, 1, 34-45.

S\&P. (2012). How we rate sovereigns. Retrieved May 16, 2013, from http://www.standardandpoors.com/spf/ratings/How_We_Rate_Sovereigns_3_13_12.pdf

S\&P. (2013a). Sovereigns. Retrieved May 16, 2013, from http://www.standardandpoors.com/ratings/sovresearch/en/us

S\&P. (2013b). Sovereign rating and country T\&C assessment histories. Retrieved July 6, 2013, from http://www.standardandpoors.com/spf/upload/Ratings_US/TC_Assessment_Histories_1_4_13.pdf

SEC. (2011). Disclosure for asset-backed securities required by Section 943 of the Dodd-Frank Wall Street reform and consumer protection act. Retrieved June 22, 2013, from http://www.sec.gov/spotlight/dodd-frank/creditratingagencies.shtml 
Shiller, R.J. (2008). The subprime solution: How today's global financial crisis happened and what to do about it. Princeton: Princeton University Press.

United States Senate, Permanent Subcommittee on Investigations, Committee on Homeland Security and Government Affairs. (2011). Wall Street and the financial crisis: An anatomy of a financial collapse. Retrieved May 17 , 2013, from http://www.hsgac.senate.gov/imo/media/doc/Financial_Crisis/FinancialCrisisReport.pdf?attempt=2

White, L.J. (2001). The credit rating industry: An industrial organization analysis. NYU Center for Law and Business Research Paper, No.01-001, Newyork.

White, L.J. (2009). A brief history of credit rating agencies: How financial regulation entrenched this industry's role in the subprime mortgage debacle of 2007-2008. Mercatus on Policy, No.59, Arlington, VA.

White, L.J. (2010). Credit rating agencies and the financial crisis: Less regulation of CRAs is a better response. Journal of International Banking Law and Regulation, 25(4), 170-179. 